\title{
All by myself. Research into employees' informal learning experiences
}

Citation for published version (APA):

Van der Klink, M., Boon, J., \& Schlusmans, K. (2012). All by myself. Research into employees' informal learning experiences. International Journal of Human Resources Development and Management, 12(1/2), 77-91.

https://doi.org/10.1504/IJHRDM.2012.044201

DOI:

10.1504/IJHRDM.2012.044201

Document status and date:

Published: 01/01/2012

Document Version:

Peer reviewed version

Document license:

CC BY

Please check the document version of this publication:

- A submitted manuscript is the version of the article upon submission and before peer-review. There can be important differences between the submitted version and the official published version of record. People interested in the research are advised to contact the author for the final version of the publication, or visit the DOI to the publisher's website.

- The final author version and the galley proof are versions of the publication after peer review.

- The final published version features the final layout of the paper including the volume, issue and page numbers.

Link to publication

\section{General rights}

Copyright and moral rights for the publications made accessible in the public portal are retained by the authors and/or other copyright owners and it is a condition of accessing publications that users recognise and abide by the legal requirements associated with these rights.

- Users may download and print one copy of any publication from the public portal for the purpose of private study or research.

- You may not further distribute the material or use it for any profit-making activity or commercial gain

- You may freely distribute the URL identifying the publication in the public portal.

If the publication is distributed under the terms of Article 25fa of the Dutch Copyright Act, indicated by the "Taverne" license above, please follow below link for the End User Agreement:

https://www.ou.nl/taverne-agreement

Take down policy

If you believe that this document breaches copyright please contact us at:

pure-support@ou.nl

providing details and we will investigate your claim.

Downloaded from https://research.ou.nl/ on date: 26 Apr. 2023 


\title{
All by myself. Research into employees' informal learning experiences
}

\section{Marcel van der Klink*, Jo Boon and Kathleen Schlusmans}

Open University of the Netherlands, Heerlen, PO Box 2960, 6401 DL Heerlen, The Netherlands

E-mail: Marcel.vanderklink@ou.nl

E-mail: Jo.boon@ou.nl

E-mail: Kathleen.schlusmans@ou.nl

*Corresponding author

\begin{abstract}
Informal learning is seen as an important phenomenon in the contemporary era of lifelong learning. This study examined informal learning activities and its outcomes as well as the factors that influenced, either positively or negatively, informal learning. In total 24 employees of the Dutch Open University were interviewed about their main informal learning experiences over the last two years. Findings revealed that the majority of the informal learning outcomes are skill-based, generic and applicable in a larger cluster of jobs than participants' present jobs. Participants favoured learning activities that allow high levels of internal locus of control. The main stimulus for informal learning lies in the changing demands of their daily job. Other organisational, job and employee characteristics, such as age, job tenure, attitude of supervisor and colleagues, hardly influenced participants' informal learning. The article concludes with some critical remarks on the value of informal learning from the perspective of lifelong learning.
\end{abstract}

Keywords: Informal learning; transfer of learning; lifelong learning; factors affecting informal learning.

Reference to this paper should be made as follows: Van der Klink, M., Boon, J. and Schlusmans, K. (2012) 'All by myself. Research into employees' informal learning experiences', Int. J. Human Resources Development and Management, Vol. 12, Nos. 1/2, pp.77-91.

Biographical notes: Marcel van der Klink is an Associate Professor at the Centre of Learning Sciences and Technology (Celstec) of the Open University of the Netherlands. His research focuses on various aspects of human resource development, including assessment and e-learning. He is the co-author of several books, and special issues and many articles and papers. He is a member of the editorial board of Human Resource Development International and Impact, a journal specialised in e-learning in the workplace.

Jo Boon is the HRM Manager at the Centre of Learning Sciences and Technology (Celstec) of the Open University of the Netherlands. At the same time she works as an Associate Professor at Celstec. Her research focuses on professional development and learning. 
Kathleen Schlusmans is currently the Manager of Educational Innovation and Quality Assurance at the Open University of the Netherlands. Her work focuses on providing open and flexible lifelong learning opportunities for adult learners. Her interests include instructional design, e-learning and open educational resources.

\section{Introduction}

Over the last 30 years several studies contributed to our understanding of the significance of informal learning in everyday life. Very well known is, for example, the research of Tough (1979) on everyday learning experiences of adults who were engaged in self-defined and self-guided learning projects. Tough discovered that adults are able to structure their own learning by setting goals, undertaking activities and evaluating outcomes of their learning activities. Another well-known study on informal learning that enhanced our understanding of this phenomenon was conducted by Lave and Wenger (1991) who reported detailed descriptions on how in various vocations learning is embedded in the active participation in everyday working experiences. Those studies showed that formal learning only represents a minor fraction of the learning that takes place in the workplace. Some studies attempted to foster the scope of informal learning, like Marsick's study (2006) who argued that $60 \%$ to $80 \%$ of the learning in today's workplace occurs informally, whereas Canadian national surveys revealed that even $82 \%$ of the employees considered themselves to be engaged in job-related informal learning with an average of six hours a week (Livingstone and Eichler, 2005).

Informal learning has become commonplace; in the literature, numerous synonyms can be found, such as incidental learning, learning 'en passant', non formal learning, experiential learning, action learning, tacit knowing (Marsick and Volpe, 1999). In the early nineties of the last century, informal learning and formal learning were perceived as two distinct categories. Nowadays there seems to establish growing understanding among scholars for considering informal learning and formal learning as both ends of a continuum (Van der Klink and Streumer, 2004) and the issue of definition seems to become less manifest in present scholarly discussions. This article adopts the definition of Marsick and Volpe (1999) who defined informal learning by using six characteristics:

1 integrated with work and daily routine

2 triggered by an internal or external jolt

3 not highly conscious

4 often haphazard and influenced by change

5 an inductive process of reflection and action

6 linked to the learning with others.

Since informal learning can be considered as one of the main vehicles for lifelong learning this article attempts to contribute to our understanding of the what, why and how of employees' informal learning experiences. The article presents a study on the 
workplace learning experiences of university employees, academic and non-academic staff and on the factors that contribute, positively or negatively, to their informal learning.

\section{Factors influencing informal learning}

What and how employees learn informally is to a large extent connected to individual factors and factors embedded in the workplace itself. Here both categories of factors will be briefly discussed.

Studies conducted by Van Woerkom (2003), Koopmans (2006), and Knight et al. (2006) offer interesting insights into professionals' informal learning experiences. These studies stress informal learning as a partly deliberate, staged, and iterative process. Content and quality of the informal learning depends to a considerable extent, on the presence of three learning competences:

1 reflection

2 preparation of learning by goal setting

3 monitoring of learning activities.

Informal learning experiences often start with the reflection on a situation or problem which allows the learner to go beyond a 'taken for granted' perspective and to consider goals and necessary actions to achieve these goals (Jarvis, 1987). Though reflection is crucial, it is not sufficient since reflection as such does not lead to change. Reflection needs to be followed by goal setting and then followed by monitoring while carrying out learning activities to assure that particular learning goals are really achieved (Zimmerman, 2006).

It is important to emphasise that not all informal learning experiences can be characterised as planned learning experiences that resembles the sequence of reflection, goals and monitoring. Based on interviews with 78 learners, Spear and Mocker (1984) demonstrated that conscious and deliberate planning of learning activities is even quite rare. As Ellinger (2004) concluded in her review, learners more often respond to circumstances and events rather than planning carefully in advance their courses of actions. Many informal learning experiences occur as a side-effect of some other activity and it even occurs although employees are not always conscious of it and they do not intentionally seek for learning experiences. Since informal learning is partly tacit, learners do not always recognise what they actually have learned. In many cases adults experience considerable difficulties with recalling, evaluating and discussing their own informal learning experiences since they do not define informal learning as 'learning' but as 'working' or as 'problem solving' (Nijhof et al., 2006).

In addition to abovementioned learning competences, individual and organisational characteristics affect employees' informal learning. Raemdonck (2006) reported that adults differ strongly in their competences to perform as self-directed learners in the workplace. The assumption that educational background correlates strongly with self-directed learning in the workplace was not confirmed in her studies. Thus a higher education degree is not a guarantee for adults' self-directedness. Comparable findings were reported by Van der Heijden et al. (2009) which did not demonstrate either a strong relationship between educational levels on the one hand and the nature and amount of informal learning on the other hand. It is more likely that the attitude toward being 
engaged in learning and experimenting affects the willingness to learn informally (Onstenk, 2004). Evidence suggests that a proactive personality and a will to seek for and utilise available opportunities for learning contribute significantly to employees' readiness for informal learning at work (Van Eekelen et al., 2006).

Numerous organisational factors shape informal learning in the workplace. Research studies into workplace learning point at the significance of

a feedback and support of co-workers and managers respectively

b the learning climate (acceptance and time for experimenting on the job)

c workload

d autonomy in the performance of tasks and duties (see for example Ashton, 2004;

Skule, 2004; Van der Klink and Streumer, 2004).

Though organisational conditions to learn informally at work differ strongly between jobs, companies and branches, there seems to exist a broadly shared understanding that contemporary workplaces do not provide sufficient space to reflect thoroughly on work, learning and career (Boud, 2006). A shift in responsibility from the workplace (employer) to the individual (employee) can be seen, this explains the rise of all kinds of initiatives to enhance opportunities for informal learning. This underscores the fact that most workplaces do not allow workers to consider thoroughly opportunities for their own informal learning (Poell, 2006; Tjepkema, 2003).

To sum up, it may be stated that informal learning is one of the main vehicles for lifelong learning and there are many factors that are linked to employees' informal learning. This study focuses on employees' informal learning activities, its outcomes and the factors that influence their informal learning. After a brief description of the applied methodology the main findings of this study will be presented, followed by some concluding remarks.

\section{Research questions and methodology}

This study seeks to address the following questions:

1 What kinds of learning activities and learning outcomes are reported?

2 Is informal learning perceived as an effective way of learning?

3 To what extent do participants make use of learning competences, such as reflection, goal setting, monitoring and pro-activity for steering their own informal learning?

4 What is the impact of job, organisational and employee characteristics on the reported learning activities and its outcomes?

All participants were employed at the Open University of the Netherlands. A stratified sample was used, involving 12 employees working in academic jobs and 12 in non-academic jobs. Male (12) and female (12) participants were equally divided over both types of job positions. Participants were selected from different departments/faculties of the university.

It was decided to opt for semi-structured interviews covering the following topics: 
1 employee characteristics, such as gender, education level, job tenure, career and age

2 learning outcomes, participants' recall of their most significant informal learning experiences in the last two years

3 learning activities: all the activities undertaken to achieve the learning outcomes

4 organisational and job characteristics such as job tasks and recent changes in job tasks, and other circumstances that likely impact participants' informal learning (e.g., work pressure, behaviour manager)

5 participants' ratings of their learning competences on a scale varying from $1=$ not present to $3=$ high level.

The first six interviews were used to pilot the interview scheme, resulting in minor changes in the phrasing and order of the interview topics. All participants accepted the invitation for a face-to-face interview. They received the interview scheme beforehand to allow for preparation. The interviews which lasted about an hour, took place during the months April to June 2008. The participants received a written report of the interview to check for accuracy.

All the data were grouped per interview question. The three researchers analysed the data through the lens of tracing similarities, trends and patterns. Some of the participants' answers were scored with the use of pre-defined categories. This was performed for the types of learning outcomes (these were distinguished into three categories: 1 = knowledge, 2 = skills and 3 = attitudes), and the transferability of the learning outcomes $(1=$ specific/job related, $2=$ generic, $3=$ very generic $)$. Here some additional explanation on this scoring will be given. Examples of learning experiences that were grouped into the category 'skills' are, for example, learning editorial duties or learning how to handle the new software in the lending library. These examples show that in this study the notion of skills is not restricted to routine skills with low complexity. Skills usually are quite complex and require the application of all kinds of (advanced) knowledge on facts, procedures etcetera. Learning outcomes in the category 'attitude' have in common that they refer to change in perceptions, values etcetera. An example in this study is: becoming more extraverts in contacts with others. Examples of learning outcomes that were classified as 'knowledge' were: learning to better understand organisational change processes, or to have more insights into the latest views on assessments.

The scoring of the qualitative data in pre-defined categories was performed mutually by the three researchers. In all cases they were able to agree upon the scoring, however, the classification of the learning outcomes into knowledge, skills and attitudes appeared to be rather complex. Next, researchers' scores were stored in a spss file which allowed performing additional non-parametric analyses in order to seek for learning patterns.

Finally variables were computed for learning activities. The number of times a participant mentioned a particular learning activity was grouped into one variable. Thus when a participant mentioned, for example, three learning outcomes and for acquiring each learning outcome he applied individual learning by doing, then his total score on this variable is 3 . Computing these new variables was restricted to the three most often applied learning activities that were reported by the participants. 


\section{Results}

Here we present our findings on an aggregated level. First we will present the findings grouped into the various categories of variables, followed by more in-depth analyses to explore possible relationships between variables.

\subsection{Employee characteristics}

Half of the participants had worked over ten years at this university, and on average performed their current job for about six years. The average age was 48 but only four participants were younger than 40. Participants with non-academic jobs were employed in various kinds of jobs, like secretary, assistant manager or project manager. Participants with academic jobs were mainly employed as assistant or associate professor. All participants, except one, attended some form of higher education. When participants were asked to compare their present job with their job two years ago, their answers indicated that in general their job tasks did not really change significantly but 13 participants mentioned some modest changes in the content of their job.

\subsection{Learning outcomes}

Participants were invited to recall two or three significant informal learning experiences they were engaged in during the last two years and to indicate the reasons and motives for these learning experiences. Although some of them expressed that this was a tough question all of them were able to recall at least two significant learning experiences. In total, they recalled 64 learning outcomes. Participants' answers showed, without any exception, that learning endeavours were closely related to their current job tasks and by the changes that occurred in these tasks: 'My work demanded it' or similar expressions were used by the vast majority of participants:

\footnotetext{
"You run into things you cannot do or you don't know and you are the one who is bothered by this. So you have to start learning ..."

"Stress was the main reason for starting to learn, because I did all these work activities in a parallel order. Then I decided to involve my students in my own research activities and so I managed to establish some synergy between my various job tasks"
}

The content of participants' learning experiences showed a broad range, from learning to be able to perform a very advanced and complex statistical procedure to learning to being able to put things more into perspective. In total, participants mentioned 17 learning outcomes that were labelled by the three researchers as knowledge, 35 and 12 were respectively labelled as skills and attitudes.

Next learning outcomes were distinguished into the degree of transferability, indicating the degree in which the achieved learning outcome is also transferable to other jobs than participants' current jobs. Fifteen learning outcomes were labelled as specific/job related, 28 as generic and 21 were perceived as very generic. Very generic implies that these learning outcomes can be applied into a large number of jobs in different branches and sectors. A project management skill is an example of a learning outcome that was labelled as very generic. The findings regarding the nature and the transferability of the learning outcomes are summarised in Table 1. 
Table 1 The nature of the learning outcomes and their transferability

\begin{tabular}{lcccc}
\hline & Specific/job related & Generic & Very generic & Total \\
\hline Knowledge & 10 & 6 & 1 & 17 \\
Skills & 4 & 21 & 10 & 35 \\
Attitudes & 1 & 1 & 10 & 12 \\
Total & 15 & 28 & 21 & 64 \\
\hline
\end{tabular}

More than half the outcomes (35 of 64) were classified as skills. Learning outcomes in the categories knowledge and attitudes were both responsible for about $20 \%$ of the reported outcomes. The classifications of the transferability of the outcomes indicate that about one fourth of the outcomes were only applicable in respondents' current job whereas 49 outcomes were labelled as generic or very generic, respectively.

\subsection{Learning activities}

Participants were asked to recall the learning activities which were most significant for acquiring their reported learning outcomes. During the interviews we invited them first to recall spontaneously and afterwards we presented them a list of learning activities to choose from, to a maximum of three activities in total per learning outcome. The top three of learning activities consists of individual learning by doing (mentioned 32 times), talking to colleagues (mentioned 29 times), and reading literature or websites (mentioned 26 times), respectively. Table 2 presents the three most applied learning activities, related to the three different types of learning outcomes.

Table 2 The most frequent applied learning activities divided over the three types of learning outcomes

\begin{tabular}{lcccc}
\hline & Knowledge & Skills & Attitudes & Total \\
\hline Individual learning by doing & 3 & 20 & 9 & 32 \\
Talking to colleagues & 8 & 15 & 6 & 29 \\
Reading literature and websites & 13 & 12 & 1 & 26 \\
\hline
\end{tabular}

The figures displayed in Table 2 demonstrate that individual learning by doing is predominantly performed for acquiring skill-based learning outcomes. Talking to colleagues is a frequent applied activity, irrespectively the nature of the learning outcome, while reading literature and websites is frequently applied for learning outcomes that belong to the categories knowledge and skills, respectively.

Though some activities were often mentioned by the participants, others were hardly mentioned at all, like participation in projects (mentioned three times), discussions in the own team, and e-mailing to colleagues (both mentioned two times).

When asked to consider the effectiveness of their informal learning activities, participants' responses were mixed. Some participants felt that they had learned much more and more effectively too than they would have in a course or workshop:

"The thing I learned, I could never have learned in a formal setting"

"I'm very satisfied with what I've learned. I have the feeling that I'm so competent because I have to find out it all by myself" 
Others, however, felt that it would have been more productive if they had started with a short workshop were the tricks of the trade were presented:

"I just jumped in, but looking back it would have been better if someone had warned me and had given me some advice on how to go about."

In some interviews participants mentioned their work environments did not provide sufficient encouragements for undertaking learning activities at work:

"I sense I miss some things. I have an autonomous job and no colleagues with similar job tasks. So there is no one in this department I can turn to for collegial discussions about my work."

\subsection{Learning competences}

Participants were asked to evaluate their own learning competences for informal learning on a scale from 1 (absent/low) to 3 (high). The findings revealed they felt in general competent in reflection (mean 2.35) and pro-activity (mean 2.52), but far less so in setting goals (mean 1.79) and monitoring the course of their learning activities (mean 1.61). Monitoring was only mentioned in relation to performance appraisal activities and it turned out that participants only monitored their (informal) learning activities when asked to do so. As far as setting goals was concerned participants felt they should spend more time and effort on setting goals but they did not do it:

"'I am not very good at setting goals, there are too many things I like and I do not make enough choices. If I set myself goals, but they are quite vague, I do not really decide where I want to go in my career and deliberately align my learning goals... Maybe I should do this more."

Non-parametric correlations (Spearman's rho, two-tailed) showed some interrelatedness between learning competencies. Pro-activity correlated positively with monitoring $(r=.53, p<.01)$. Some of the observed correlation coefficients did not reveal strong links but can nevertheless be considered as trends. This was the case for the relationship between pro-activity and setting goals $(r=.39, p<.07)$ and monitoring that correlated positively with setting goals $(r=.36, p<.09)$.

\subsection{Organisational conditions}

Participants were invited to reflect on the three most important organisational factors that contributed, positively or negatively, to their informal learning. It was interesting to note that the same factors can have a positive or a negative influence on learning. Factors with a positive influence outweigh the negative ones.

The most important often reported positive factor is the content of the job itself (20), this determines most if people learn or not. The second one is the behaviour of participant's manager (ten), followed by perceived career possibilities (eight) and behaviour of participants' team members (seven).

The most important negative factor is pressure at work (seven) which results in not having sufficient time to learn:

"Everything has to be task-related and sometimes you learn more if you can talk about other things as well with your colleagues" 
However, three participants mentioned that pressure at work had a positive influence; it urged them to learn quickly to get things done:

"If I had more time I would go to courses and conferences but now I have to learn everything quickly by myself."

\subsection{The impact of employee, job and organisational characteristics on informal learning}

Crosstabs and non-parametric tests were computed to further explore the impact of employee characteristics (age, sex, job tenure, years employment at OUNL) job characteristics (academic-versus non-academic job position, changes in tasks over past two years) and organisational characteristics (behaviour manager, career possibilities, behaviour team members) on the type and transferability of the learning outcomes, the applied learning activities and learning competences, respectively. Here the main findings will be reported.

First the relationship between the various characteristics and the types of learning outcomes will be discussed. The most striking findings are displayed in Table 3. Male participants mentioned more often knowledge as a learning outcome, while female participants mentioned more often skills. Participants who indicated there was a change in the content of their job more often mentioned skills as learning outcome: $71 \%$ of all learned skills were mentioned by participants who reported some changes in the content of their job over the last two years. The length of time one works in a job is related to the nature of the learning outcome. Participants who worked less than six years in their current job mainly reported skills as learning outcomes $(61 \%)$. Though these were the most striking findings Chi-square tests revealed that there appears to exist a close link between job change and type of learning outcomes: $\mathrm{X}^{2}(2, n=24)=8.80, p=.025$ but these close links were not observed for gender and years in current job.

Table 3 Employee and job characteristics and the types of learning outcomes

\begin{tabular}{lcccc}
\hline & Knowledge & Skills & Attitudes & Total \\
\hline Man & $12(38 \%)$ & $15(47 \%)$ & $5(16 \%)$ & $32(100 \%)$ \\
Women & $5(16 \%)$ & $20(63 \%)$ & $7(21 \%)$ & $32(100 \%)$ \\
Job change yes & $6(17 \%)$ & $25(71 \%)$ & $4(11 \%)$ & $35(100 \%)$ \\
Job change no & $11(38 \%)$ & $10(34 \%)$ & $8(28 \%)$ & $29(100 \%)$ \\
$<6$ years in current job & $8(22 \%)$ & $22(61 \%)$ & $6(17 \%)$ & $36(100 \%)$ \\
Six to ten years in current job & $6(28 \%)$ & $10(48 \%)$ & $5(24 \%)$ & $21(100 \%)$ \\
$>10$ years in current job & $3(50 \%)$ & $2(33 \%)$ & $1(17 \%)$ & $6(100 \%)$ \\
\hline
\end{tabular}

The impact of the various employee, job and organisational characteristics on the transferability of learning outcomes is displayed in Table 4 . Here only the main findings will be reported. Male participants tend to acquire more often learning outcomes that can be characterised as specific/job-related. Participants who indicated that during the past two years some changes in the content of their jobs occurred tend to more often report learning outcomes that can be characterised as generic, while participants who stated their job did not change report more often learning outcomes in the category specific/job-related. There seems to exist a link between age and transferability. 
Participants younger than 41 more often mentioned learning outcomes in the category very generic compared to participants over 50. The latter group of participants more often mentioned learning outcomes that can be considered as specific/job-related. However, Chi-square tests revealed only a close link between job change and transferability of learning outcomes $\mathrm{X}^{2}(2, n=24)=6.48, p=.05$ but not for the other two variables displayed in Table 4.

Table 4 Employee and job characteristics and the transferability of learning outcomes

\begin{tabular}{lcccc}
\hline & Specific/job related & Generic & Very generic & Total \\
\hline Man & $10(31 \%)$ & $13(41 \%)$ & $9(28 \%)$ & $32(100 \%)$ \\
Women & $5(16 \%)$ & $14(44 \%)$ & $13(41 \%)$ & $32(100 \%)$ \\
Job change yes & $4(11 \%)$ & $18(51 \%)$ & $13(37 \%)$ & $35(100 \%)$ \\
Job change no & $11(38 \%)$ & $9(31 \%)$ & $9(31 \%)$ & $29(100 \%)$ \\
Age $<41$ & $1(8 \%)$ & $5(38 \%)$ & $7(54 \%)$ & $13(100 \%)$ \\
Age $41-50$ & $6(21 \%)$ & $12(43 \%)$ & $10(36 \%)$ & $28(100 \%)$ \\
Age $>50$ & $8(35 \%)$ & $10(43 \%)$ & $5(22 \%)$ & $23(100 \%)$ \\
\hline
\end{tabular}

Further analysis of the data regarding learning activities was restricted to the three main learning activities that were reported by the participants: individual learning by doing; talking to colleagues; reading literature and websites.

None of the job characteristics was related with the number of times these three learning activities were carried out and only one employee characteristic appeared to be linked. Participant's employment tenure at this university correlated negatively with talking to colleagues $(r=.36, p<.09)$, as non-parametric correlations showed (Spearman's rho, two-tailed), indicating that with an increase of years employed at this university participants tend to rely less on their colleagues as a source for learning. In addition, the analysis revealed that reflection, one of the four learning competences, correlated positively with reading literature and websites $(r=.42, p<.04)$.

Finally, the analysis focused on the possible impact of the employee, job and organisational characteristics on participants' learning competences. A Mann-Whitney $U$ test revealed a weak significant difference in the pro-activity levels of females $(M d=3$, $n=11)$ and males $(M d=3, n=12), U=43, z=-1.75, p=.08, r=.36)$, indicating that female participants reported higher pro-activity levels than their male participants did. Participants who mentioned the availability of career possibilities as an important condition for their informal learning more often reported higher levels on their goal setting competence $(M d=2, \mathrm{n}=8)(M d=1, n=16), U=33,5 z=-2.01, p=.06, r=.41)$ but here too the link seems to be fairly modest.

\section{Conclusions and discussion}

The main goal of this study was to analyse the character of informal learning and to increase our understanding of employees' informal learning experiences. In total 24 employees of the Dutch Open University were interviewed about their informal learning experiences and the factors that contributed, positively or negatively, to their informal learning. First we will attempt to address the research questions, followed by methodological considerations and some issues that require further discussion. 
The first research question concerns the kinds of learning activities and learning outcomes. The findings clearly demonstrate the broad range of learning outcomes reported by the participants varying from knowledge, skills and attitudes. To specify these outcomes, the job specificity of the outcomes was considered; this reveals that most of the learning outcomes can be labelled as generic or very generic and only a limited amount of learning outcomes was labelled as specific/job related. The fact that learning outcomes show a scattered picture about what is learned and does not show simultaneous competence development of the whole cluster of knowledge, skills and attitudes, prompts us to question the value of what is learned for the fulfilment of the job. It can be assumed that it is beneficial to upgrade generic skills but one can suppose that a more systematic approach to learning, both formal and informal, would reveal a more complete range of competences to be trained.

All learning outcomes have in common that they are strongly related to participants' job tasks and changes in these tasks. Although the jobs themselves might not have changed so much, even minor changes in work methods, equipment and policies provide ample opportunity for informal learning at work. So in most cases this learning is not completely deliberate but more or less forced by changes in participants' jobs. Most learning outcomes however are not restricted to participants' jobs. The majority of these learning outcomes are more generic in nature and can also be applied in other settings than participants' current jobs. In the light of the rapid changing, dynamic labour market and the increasing need to remain employable throughout the entire career these results would be very promising. Our findings that informal learning outcomes are not restricted to current jobs settings are not in accordance with the results of several researchers who have pointed out the lack of transfer as a negative side-effect of informal learning (see, for example, Nijhof et al., 2006).

Three learning activities most often mentioned by the participants are 'individual learning by doing', 'talking to colleagues', and 'reading literature/websites'. Participants obviously favoured activities with high levels of internal locus of control. Activities that require more collaboration, such as discussions in meetings or participation in projects were not or hardly mentioned. Informal learning is in fact a lonely activity, where not only an explicit consideration or feedback is lacking about the learning that is needed to fulfil a job, the results also show that the learning process itself is very often an individual action undertaken. These results concur with findings of previous studies among professionals (e.g., Kwakman, 2003). From the 102 answers given on the question how one learned, only 29 refer to learning by communicating with others. It is noticeable here that also learning from virtual communities is not mentioned as a powerful way of learning. Given the considerable amount of social media and the fact that virtual networking belongs to the core business of this university it could have been expected to be more important.

When learning activities are combined with types of learning outcomes it appears that 'individual learning by doing' and 'talking to colleagues' are the two activities most often undertaken for the acquisition of skills, whereas knowledge-based learning outcomes are more related to 'reading literature and websites'. Apparently, there exist some patterns between learning activities and type of outcomes. However, the limited number of participants in this study does not allow firm conclusions in this respect.

The second research question goes into the efficiency of informal learning. The general picture of this study about the character and the efficiency of informal learning is that participants themselves evaluate their learning in a positive way, but not as a 
systematic or vital activity. When asked to consider the effectiveness of their informal learning activities, participants' responses were rather mixed. Some respondents felt that it would have been more productive if they had started with a formal training, others mention the lack of support of their work environment. In the whole the picture of informal learning as we encountered it in this research does not indicate a picture of efficiency. The picture is that the content of the job is the main factor driving people to learn, small changes in the job incite to learn new things, that also means that doing the same job for a long time is detrimental to learning. There seems to be almost no discussion or feedback of management or colleagues about changes in competency requirements and learning plans. The positive element is that participants themselves are in general satisfied with their learning.

The relevance of the question of the efficiency of informal learning is stressed by the results from a survey conducted within the same university showing that participation in formal learning activities appeared to be modest. On average employees participated for four days in formal job-related training and three days in other formal training activities during the last 12 months (van der Klink et al., submitted). This means that this university strongly relies on informal learning as a way to update and upgrade competences.

The third research question concerns the participants' levels of their learning competences for informal learning. Previous studies, (see, for example, Zimmerman, 2006; Van Eekelen et al., 2006) indicated the need for learning competencies such as pro-activity, goal setting, monitoring and reflection. At the same time however these studies revealed the lack of these competences among substantial groups of employees.

In our study the evaluation of the own competences regarding learning reveals a weak score especially in the goal setting (mean 1,79 ) and in the monitoring of the own learning activities (mean 1.61), reflexion (mean 2.35) and pro-activity (mean 2.52) seem to be further developed.

Since the findings show that these first two learning competences are not fully developed it appears that participants' informal learning is only to a limited extent a deliberate act and seems to be primarily determined by the here and now of the immediate job demands. Our findings are in line with the notions expressed by Ellinger (2004) who states that the idea of the learner as a self-directed learner who oversees different options and carefully plans and monitors his own learning trajectory and career is perhaps more an ideology than an empirical proven fact (Van der Klink et al., 2007).

The fourth research question deals with the various characteristics of the employee, the job and the organisation that shape the participants' informal learning activities and its outcomes. With regard to organisational characteristics the participants mentioned much more conditions with a positive impact on their informal learning than negative ones. The findings suggest that participants' informal learning is mainly stimulated by their current job tasks. The effect of other organisational or job characteristics is, according to the participants statements, quite modest or even absent. This was also observed in the results of the non-parametric analyses which did not reveal multiple or strong relationships. The impact of employee characteristics on informal learning seems to be slightly more significant. For example the learning outcomes mentioned by the female participants were more often classified as skills instead of knowledge and were also more often classified as generic instead of specific. Though older participants (over 50) reported more often specific, job related outcomes the non-parametric analysis provided no evidence to suggest a strong relationship between ages and learning outcomes. Nevertheless these findings concur with an extensive body of research 
claiming that with the increase of age employees become more focused on their current (restricted) job demands (Van der Heijden et al., 2009) and are less engaged in learning experiences that result into broadly applicable skills and knowledge. From an employability perspective this can be considered as less favourable.

The analysis of possible links between organisational, job and employee characteristics on the one hand and learning outcomes and learning activities on the other hand revealed some relationships, but in general one can state that the number of links and their strengths are quite modest. The same applies for the investigation of links with participants' learning competences. Some characteristics seem hardly to matter at all. This holds, for example, for the nature of the job position (academic versus non-academic). The only factor that appeared to be influential was the change in jobs. When participants indicated some changes in their job over the last two years they more often reported skill-based learning outcomes and their learning outcomes appeared to be more transferable to other jobs.

With regard to the set up of this study the following advantages and limitations need to be taken into account. Firstly, Ashton (2004) criticised the current body of studies into informal learning, since the majority investigated small samples, with an almost exclusive focus on the learning process itself, ignoring all kinds of factors related to jobs and organisational structures. These points were taken into account during the set up of our study. Though a number of 24 participants seem to be quite modest, compared to other qualitative studies in the domain of informal learning (see, for example, Koopmans, 2006; Van Eekelen et al., 2006) a group of 24 is quite substantial. This was confirmed by our data. The last interviews did not really deliver new insights and thus saturation of the main concepts was achieved with this group of 24 participants. On the other hand the number of participants does not allow firm conclusions regarding the patterns between various employee-, job- and organisational characteristics on the one hand and informal learning activities, learning outcomes and learning competencies on the other. The number of participants is too modest for the application of advanced statistical techniques and cautious interpretation of the non-parametric statistical techniques is of utmost importance.

Secondly, all data were collected within the same organisation, i.e., the Open University of the Netherlands, which reduces the possibilities for generalising our findings. As we stated, it was not our purpose to strive for generalisation. Including different employee categories, working in different departments in different kinds of jobs, allowed us to investigate a heterogeneous purposeful sample with sufficient attention for the various organisational and job characteristics that shape informal learning.

Thirdly, the sample does not allow to draw conclusions about the quantitative occurrence of informal learning in the organisation. Nor can we draw conclusions about the total range of informal learning activities, as we asked respondents to focus on the two or three main informal learning experiences in the last two years. Thus the study did not capture the entire range of participants' informal learning experiences.

For further research we recommend to consider expanding the number of participants in order to allow the application of more powerful statistical techniques. Though surveys are often applied for collecting data of large respondent groups, and even have been applied for studies into informal learning as the studies of Borghans et al. (2006), Lohman (2005) and Skule (2004) demonstrated, there is a danger that surveys do not capture the nuances and subtleties that are usually attached to informal learning experiences (see Nijhof et al., 2006). This is especially a concern since our interviews 
revealed that many respondents experienced difficulties in recalling their informal learning experiences. In our study we applied an indirect approach by first inviting participants to list their current job tasks and the changes that occurred in their work over the past two years and subsequently we asked them to recall their informal learning. This indirect approach is recommendable because simply posing the question 'what did you learn in your work?' will presumably not result into rich and adequate descriptions of employees' learning experiences. Apparently, respondents need some time and triggers that enable them to better recall their informal learning. It is questionable whether surveys will offer the right stimuli to support respondents in this respect. A possible solution, though quite costly, was proposed by Raemdonck (2006) who used questionnaires for investigating the learning competencies of lower qualified workers but assured that these were individually administered in face to face sessions with a researcher.

Finally we would like to emphasis further research into recalling prior informal learning experiences since the rise of procedures for accreditation of prior learning, for employees' individual development plans, and for other kinds of assessments that attempt to collect employee's reservoir of prior learning experiences as a starting point for future learning endeavours. Most procedures 'assume' that employees are able to produce their prior learning immediately without any cues and triggers. Our research proved that this assumption is invalid. If we want employees to reflect on their informal learning experiences then we need to be serious about delivering the right learning infrastructure that enables them to do so.

Our study showed that it remains questionable to what extend informal learning can be considered as a powerful and efficient way to improve employees' competences. An organisational HRD policy that primarily relies on the power of its employees' informal learning activities seems to be insufficient to secure competency development and is perhaps even very hazardous for assuring employees' employability in the long run.

\section{References}

Ashton, D.N. (2004) 'The impact of organisational structure and practices on learning in the workplace', International Journal of Training and Development, Vol. 8, pp.43-53.

Borghans, L., Golsteyn, B. and De Grip, A. (2006) Meer werken is meer leren. Determinanten van kennisontwikkeling, (More working is more learning. Determinants of knowledge developments), CINOP, Den Bosch, the Netherlands.

Boud, D. (2006) 'Creating the space for reflection at work', in Boud, D., Cressey, P. and Docherty, P. (Eds.): Productive Reflection at Work, pp.158-169, Routledge, London/New York.

Ellinger, A. (2004) 'The concept of self-directed learning and the implications for Human Resource Development', Advances in Human Resources Development, Vol. 6, No. 2, pp.158-177.

Jarvis, P. (1987) Adult Learning in the Social Context, Croom Helm, London.

Knight, P., Tait, J. and Yorke, M. (2006) 'The professional learning of teachers in higher education', Studies in Higher Education, Vol. 31, No. 3, pp.319-339.

Koopmans, H.J.M. (2006) Professionals Organiseren Informeel Leren (dissertation), Eburon, Delft.

Kwakman, K. (2003) 'Factors affecting teachers' learning participation in professional learning activities', Teacher and Teacher Education, Vol. 19, pp.149-170.

Lave, J. and Wenger, E. (1991) Situated Learning: Legitimate Peripheral Participation, Cambridge University Press, Cambridge. 
Livingstone, D.W. and Eichler, M. (2005) 'Mapping the field of lifelong (formal and informal) learning and (paid and unpaid) work', Joint keynote at the Future of lifelong learning and Work International Conference, 20th June 2005, Toronto.

Lohman, M.C. (2005) 'A survey of factors influencing the engagement of two professional groups in informal workplace learning activities', Human Resource Development Quarterly, Vol. 16, pp.501-527.

Marsick, V. (2006) 'Informal strategic learning in the workplace', in Streumer, J.N. (Ed.): Work-related Learning, pp.51-69, Springer, Dordrecht.

Marsick, V. and Volpe, F.M. (1999) 'Informal learning on the job', Advances in Developing Human Resources, No. 3, AHRD and Berrett-Koehler, San Francisco.

Nijhof, W.J., Nieuwenhuis, A.F.M. and Terwel, J. (2006) 'Het leerpotentieel van de werkplek', Pedagogische Studiën, Vol. 83, No. 5, pp.335-342.

Onstenk, J. (2004) 'Leren leren tijdens het werk', in Streumer, J. and Van der Klink, M. (Eds.): Leren op de Werkplek, pp.33-49, Reed Business Information, 's-Gravenhage.

Poell, R.F. (2006) 'Personeelsontwikkeling in ontwikkeling', Naar een werknemersperspectief op Human Recsource Development (Oratie), Performa Uitgeverij, Rotterdam.

Raemdonck, I. (2006) 'Self-directedness in learning and career processes', A Study in Lower-Qualified Employees in Flanders (dissertation), Gent University, faculty of Psychological and Pedagogical Sciences, Gent.

Skule, S. (2004) 'Learning conditions at work: a framework to understand and assess informal learning in the workplace', International Journal of Training \& Development, Vol. 8, pp.8-20.

Spear, G.E. and Mocker, D.W. (1984) 'The organizing circumstance: environmental determinants in self-directed learning', Adult Education Quarterly, Vol. 35, No. 1, pp.1-10.

Tjepkema, S. (2003) The learning Infrastructure of Self-Managing Work Teams (dissertation), Twente University Press, Enschede.

Tough, A. (1979) The Adults Learning Projects, Ontario Institute for Studies in Education, Ontario.

Van der Heijden, B.I.J.M., Boon, J., Van der Klink, M.R. and Meijs, E. (2009) 'Employability enhancement through formal and informal learning: an empirical study among Dutch non-academic university staff members', International Journal of Training \& Development, Vol. 13, No. 1, pp.19-37.

Van der Klink, M. and Streumer, J. (2004) 'De werkplek als leersituatie', in Streumer, J. and Van der Klink, M. (Eds.): Leren op de Werkplek, pp.11-32, Reed Business Information, 's-Gravenhage.

Van der Klink, M., Schlusmans, K. and Boon, J. (2007) 'Designing and implementing views on competencies', in Sicilia, M. (Ed.): Competencies in Organizational E-Learning, Concepts and Tools, pp.221-233, Idea Group Inc., Hershey.

Van der Klink, M.R., Van der Heijden, B.I.J.M. and Boon, J. (submitted) Does Learning Really Matter? An Empirical Study into the Contribution of Formal Training and Informal Learning to the Employability of University Staff Members.

Van Eekelen, I.M., Vermunt, J.D. and Boshuizen, H.P.A. (2006) 'Exploring teachers' will to learn', Teaching and Teacher Education, Vol. 22, pp.408-423.

Van Woerkom, M. (2003) Critical Reflection at Work (dissertation), Twente University, Enschede.

Zimmerman, B.J. (2006) 'Development and adaption of expertise: the role of self-regulatory processes and beliefs', in Ericsson, K.A., Charness, N., Feltovich, P.J. and Hoffman, R.R. (Eds.): The Cambridge Handbook of Expertise and Expert Performance, Cambridge University Press, Cambridge. 